\title{
Chinese Students' Initially Disclosed Reasons for Studying in Canada
}

\author{
Glenn Rideout, Sirous Tabrizi \\ University of Windsor \\ Canada
}

\begin{abstract}
In Canada, international students are increasingly a part of cross-cultural exchange and make a positive contribution to bi-lateral exchange between countries. The largest source of international students for Canada is China. There could be many reasons why Chinese students may want to come to Canada instead of other countries to study. Understanding such reasons could help Universities better recruit and support new students. To explore these reasons, a survey was conducted with 55 Chinese international students in a Canadian Faculty of Education and a Faculty of Engineering. The survey suggested that some of the reasons for Chinese students choosing to study in Canada include improving English-speaking skills, the belief that Canada is a safe country, and that Canadian educational institutions are prestigious and high-quality. There were also personal reasons, such as pressure from family to study abroad and a desire to leave China.
\end{abstract}

\section{Introduction}

Over the past several years, the country from which most foreign students have come to Canada is China [11]. The numbers themselves are actually quite high: 65,600 in 2014, which is a new record for Canada [24], and shows meaningful growth when compared to the year before, in which Canada welcomed only 29,000 new Chinese students [24].

In recent years, China has been transformed into a more industrial country, with its economy continuing to grow. However, with such a large population, there is potential for high competition within the country, such as competitiveness in the economic, political, and social spheres of life and even in sports. Competitive pressures can create a desire to seek out better schooling in order to remain competitive, a desire that is sometimes met by studying abroad. However,

\footnotetext{
${ }^{1}$ Throughout this paper, "Chinese students" refers to people from Mainland China (i.e., the area controlled by the People's Republic of China, excluding Hong Kong and
}

competition is not the only reason for someone to study abroad. Such movement of students is potentially necessary for China to maintain stable economic development [31], as international students who return to China from Canada and other international destinations provide the means for brain circulation--the circuit of knowledge created as people leave one country, learn something in another country, and come back to apply and share that knowledge [14]. Such factors seem to lay the foundation for why Chinese students might travel abroad to study, hence this paper examines why Chinese students say they choose a Canadian education [25].

Bearing this context in mind, this paper reports on a study exploring why Chinese students ${ }^{1}$ ostensibly come to Canada. This is a relevant question from the perspective of scholars and post-secondary administrators who want to know how best to accommodate and/or attract new international students from China. Destination Choice theory suggests that students go through three stages when embarking on international education: the decision to study abroad, the choice of a country, the choice of an institution within that country $[2,32,26]$. For this research, the first two categories are of greater interest: why leave China, and why study in Canada. Currently there is little information about the motivations and perceptions of Chinese students in this regard.

Previous research has explored why Chinese students study abroad, though few have explicitly looked at the context of Canada. The best example is the researched conducted by Ji [20], who focused on three questions: Why do Mainland Chinese students study abroad (what factors influence their decision?); How do Mainland Chinese students choose their study abroad destination; Why do Mainland Chinese students choose Canada as their destination? However, the authors hypothesized that there may be reasons for undertaking foreign study that students are

Macau) that have traveled to another country to study. This distinction was made in the materials surveyed, and so it will be maintained here. 
more hesitant to discuss or are more difficult for them to express. For instance, when asked "why have you come to study in Canada" a student may respond with "because I want a Western education" but really the student's parents want him/her to come to Canada for this education. Such a reaction may be a result of cultural influences.

This is important to consider; if such students have unexplored or misunderstood reasons for studying in Canada, and if those reasons are not easily accessible through simply asking students via a questionnaire or survey why they travelled abroad for study, then the efforts of host scholars and institutional leaders may leave students' needs unmet and restrict future international recruiting efforts. This larger question of whether Chinese students have other, sometimes hidden, reasons for studying abroad must first be compared against whatever stated or explicit reasons Chinese students have. Such comparison will be presented in a later paper. In this paper, we will present the stated reasons and explanations given for studying in Canada.

As noted above, traditional Chinese culture appears to rest on embedded family ties and an honor system that could influence young adults' decisions regarding studying abroad, and may influence them in a manner that they may not care to articulate to 'outsiders' who do not take the time to listen to what they really have to say. Similarly, there is a politeness of communication that discourages speaking about family conflicts, challenges to authority, or personal disagreements with direct questions; such politeness may lead some Chinese students to provide reasons for international study that are distinct from their actual reason for studying due to the dishonor or conflict that would occur. If such a difference between actual and stated reasons emerges from a comparison of themes found in the literature and in the study conducted here, this may be a truly meaningful finding for the way Chinese international education is researched and measured, both from a recruiting and learning outcomes perspective.

To start this research then, the explicit or stated reasons need to be gathered in such a way that the potential for hidden or unstated reasons can potentially accessed at a later date.

\section{Literature Review}

The literature review for this study will explore the following topics: Brain drain, gain, and circulation, Cultural values, Social structure and families, Chinese focus on education, Potential benefits of studying in Canada, and Chinese students' stated reasons for studying abroad.

\subsection{Brain drain, gain, and circulation}

There have been several attempts to conceptualize the movement of educated and skilled people between countries, depending on the perspective that is taken and the movement that occurs [30]. Brain drain refers to the loss of such people from a home country, while brain gain refers to the gain of those same people. One such popular example is the 1950's United States, where numerous highly-educated people immigrated from various European countries. Brain drain and gain have recently become popular and controversial topics, due to the politics involved [30]. For example, some political policies are promoted to attract the best brains in the world, so as to generate ideas, products, patents, and profits. The ideology underlying such policy is sometimes seen as controversial since such immigrants must come from somewhere, and the loss of talented people from places such as sub-Saharan Africa for a gain in the United States, Canada, or Germany seems particularly unfair and harmful to the home country $[30,1]$.

The complexity of the situation is increased when one considers the motivation of individuals, institutions, and governments in the countries to which students travel to study. Foreign, fee-paying students are now a significant source of revenue for higher education institutions [15]. Furthermore, students in many fields, and perhaps particularly in the sciences, engineering, and technology also have potential to contribute through new ideas, products, and businesses. As such, numerous countries are trying to attract these students (such as the United States, Germany, and the United Kingdom) while other countries, such as Malaysia, are developing policies to encourage such students to return to their home country after such studies are completed [15]. Brain circulation, then, is one way of conceptualizing the movement of such students; as they leave their home country, travel to another country for education, and then return home to apply that knowledge, a cycle or circuit of knowledge is created. The problem of brain drain and gain is exacerbated when students travel to the country primarily to immigrate; the policies of countries such as Canada, New Zealand, and Australia seem to encourage this practice [3]. At the same time, movements of students (and people in general) are not isolated incidents; people often cycle between countries frequently and regularly enough that it may be inaccurate to think about the situation in terms of merely gain and drain, with 'circulation' at a global level being possibly the best way of approaching this 
phenomenon [14].

Furthermore, 'home' countries can be successful at encouraging students to return after an international education. China, India, and Russia seem to be rather effective at this currently, a situation that many researchers have failed to adequately model or explain [27]. While Canada has an immigration policy that makes it attractive for Chinese students to stay in Canada (e.g., their families can immigrate to Canada too), China also has policies in place to encourage such students to return. Although there is economic growth in China, and increasing demand for skilled and educated people, the government is also actively attempting to repatriate such students upon graduation [35]. For instance, at the end of 2012 there were 2.64 million Chinese studying abroad, 1.09 million (41\%) of which returned to China [36]. By comparison, the National Science Foundation (2012) found that of the international students who went to study in the United States: $11 \%$ of Iranian students and $4 \%$ of students from India returned home after their studies were finished [12].

\subsection{Cultural values}

Chinese people have diverse beliefs and values. There are some common ones which may persist long after immigration. These include an emphasis on the well-being of the family over individual well-being and personal rights, a desire for harmony among interpersonal relationships, respect and reverence towards elders and in particular parents, higher value ascribed to sons than daughters, and the great importance of education and literacy [8,33]. In terms of social values, Chinese society is founded upon humility, emotional self-control, family recognition through achievement, and normative conformity so as to avoid bringing shame or dishonor to the family [7].

This last point may be relevant to this research, as the status associated with honor (i.e., dignity, prestige, status in the eyes of others) within a family can be given, taken away, earned, or lost based on the actions of one person [8]. Individual decisions are often considered in terms of how it will affect the family's honor, even to the detriment of an individual's health. Hence, this consideration of family honor can influence decisions and actions of students regarding the possibility of studying abroad, and also how they express their reasons for making such choices.

\subsection{Social structure and families}

Traditional Chinese society is patriarchal and hierarchical, with two or three generations living within the same household being quite common [8]. The elders make most of the decisions and, although the eldest males tend to be the main decision makers, older women can have considerable power particularly for family and household decisions [8]. Similarly, older children tend to have more authority over younger children [7]. Women are subordinate to men, and sons are considered the breadwinners of the family; as such, sons are considered investments while daughters are considered a drain on family resources as they become part of the husband's family upon marriage $[8,5]$. This preference for sons became a problem with China's introduction of the "One Child" policy in 1979 as many female fetuses were aborted and very young daughters disappeared [17]. Some exceptions were eventually developed, such as allowing rural families with a firstborn daughter to have a second child and ethnic minority couples to have more than one child [22]. In general though, families tend to be private and do not discuss familyrelated matters with non-family members [7]. This traditional attitude towards sons and daughters may provide some foundational understanding of factors that might be brought to bear on decision-making regarding education, particularly international education, of sons and daughters of traditional Chinese families. However, these traditional values have undergone significant changes in the past half-century or so [28]; while such values are still held in several areas of the country, they appear to not be held universally throughout China.

\subsection{Chinese focus on education}

In China, people of all ages value education highly. This is part of a strong cultural tradition and deeply held beliefs that a good education guarantees a better future [10]. This means that many Chinese parents value education above everything else [39]. Children who do poorly in school are often viewed as bringing dishonor or shame to their families [8]. Some evidence for the value placed on education can be seen in various surveys. Of the families surveyed by China's National Bureau of Statistics in 2001, more than 60\% invest one-third of their annual income in the education of their children. Similarly, education was ranked second only to food in importance for income spending [32]. Of the population aged 15 years or older, $86.5 \%$ of females and $95.1 \%$ of males are literate (i.e., can read and write) [6].

If a student desires to study abroad, there are many agencies that provide information and assist people in fulfilling this desire. According to Peng [20], around $85 \%$ of applicants to Canadian schools used a 'study 
abroad' agency to help with the application for a Canadian school and a Canadian visa. Since these agencies are only paid if the student is accepted, they may sometimes engage in practices that may not always be in a student's long term best interests, to ensure a student is accepted. For instance, agencies may encourage applicants who lack the language requirements to take a short-term language course along with a short-term student visa, possibly even telling the student that this is a required pre-university program [38]. In other instances, there have been allegations that some agencies provide spurious documentation for university and visa applications so that the student, who would otherwise be ineligible, would be accepted [38].

\subsection{Potential benefits of studying in Canada}

Before examining some of the reasons why Chinese students who participated in this study might study in Canada, it could be useful to consider benefits Canada offers to international students in general. First, Canada offers students the opportunity to learn English and/or French. Second, Canada is among the countries with the lowest cost of living for international students while still maintaining a high quality of living [34]. Third, following from the previous point, even though Canadian universities tend to charge higher tuition fees for international students than domestic students, such tuition fees are still among the lowest in the world [34]. Aside from these benefits, international students also get the opportunity to interact with a wide variety of cultures, and can gain actual work experience through oncampus employment.

\subsection{Non-Chinese students' reasons for international education}

Students from countries other than China also choose to study abroad, and may have similar or different stated motivations for doing so. Some Canadian students see international education as an investment, such that experiencing a new culture and learning a foreign language would help them become more internationally competitive and competent [16]. Some American students see international education as a way of enhancing their future careers [4]. European students choose to study abroad for similar reasons: understanding a new culture and language, increasing self-knowledge and competence, and improving career prospects [13]. Students from Pakistan shared similar reasons: to obtain a higherquality education, and to improve career prospects
[19]. Some Malaysian students choose international education for career reasons--to improve their competitiveness in a global market [29]. In summary, two common threads appear to motivate such students: obtaining an education that is perceived to be of higher quality, and improving future career prospects.

\subsection{Chinese students' stated reasons for studying abroad}

Some Chinese students indicate that they study abroad for much the same reason as the non-Chinese students identified above, particularly a high quality education [18]. [37] suggested that Chinese students choose to study in the United States for several reasons: lower cost (financial aid is available), opportunity to improve their English and personal development, and the possibility of staying in the country. However, the most important reason given was personal academic achievement (i.e., higherquality education). Similarly, Yang [23] indicated that Chinese students chose to study in Australia because of the lower living cost, possibility of staying in the country, and a higher-quality education.

However, Chinese students also gave another reason for studying in Canada: the possibility of living in another country after graduation [18]. Zheng [21] found what other research found, that Chinese students chose to study in Canada because of the lower living cost, a higher-quality education, but also reported that such students were influenced by favorable government policies towards Visas (i.e., they see the possibility of remaining in Canada). This motivation is consistent with findings in other research: when studying in Western countries there could be reasons related to the perceived attractiveness of Western culture. In other words, the students come to study in a Western country because they want to gain a better understanding of Western culture, as they consider the search for liberty, freedom, and personal pleasure (i.e., pursuit of happiness) a very interesting and important aspect of their lives [9]. Given the possible interest in migrating to the host country [18, 21, 9], it is possible that the desire to live in the host country after school is an important consideration for these students.

\section{Study Methodology}

Bearing in mind the information that was gleaned from the review of literature, a study was conducted to determine whether Chinese students currently enrolled in a Canadian university had similar reasons for studying in Canada. A total of 55 Chinese international graduate students (both Master's and 
PhD level) from a university in Southwestern Ontario participated. Of these students, 25 were in the Faculty of Education and the rest were in the Faculty of Engineering. These students were given a questionnaire to fill out regarding their situation at school and the reasons for studying there. The survey was written in English, and contained 33 questions. All of the participants answered all of the survey questions, even though they were given the option to skip questions.

\subsection{Study results}

Table 1 shows the responses to the question regarding the importance of various reasons for studying in Canada. This question was meant to determine whether any of the reasons commonly listed in the literature were shared by the participants. Four issues were important for the participants: Canada's reputation and safety (i.e., a \& b), Canadian Universities certificates (i.e., c \& d), job opportunities during education process (i.e., $1 \& \mathrm{~m}$ ), and Canada as new country for them (i.e., n).

Table 1. Answers from participants to the question "how important were the following reasons in your decision to study in Canada"

\begin{tabular}{|c|l|c|c|c|c|c|}
\hline & $\begin{array}{c}\text { Reasons } \\
\text { (N=55) }\end{array}$ & I & II & III & IV & V \\
\hline a & $\begin{array}{l}\text { Canada's } \\
\text { reputation in } \\
\text { general }\end{array}$ & 2 & 1 & 10 & 42 & .000 \\
\hline $\mathrm{b}$ & $\begin{array}{l}\text { Canada's } \\
\text { reputation as } \\
\text { a safe } \\
\text { country }\end{array}$ & 6 & 2 & 21 & 26 & .000 \\
\hline $\mathrm{c}$ & $\begin{array}{l}\text { The quality } \\
\text { of education } \\
\text { in Canada }\end{array}$ & 3 & 1 & 19 & 32 & .000 \\
\hline $\mathrm{d}$ & $\begin{array}{l}\text { The prestige } \\
\text { of a } \\
\text { Canadian } \\
\text { degree or } \\
\text { diploma }\end{array}$ & 6 & 2 & 25 & 22 & .000 \\
\hline $\mathrm{e}$ & $\begin{array}{l}\text { The cost of } \\
\text { studying in } \\
\text { Canada in } \\
\text { comparison }\end{array}$ & 3 & 12 & 20 & 20 & .000 \\
\hline
\end{tabular}

\begin{tabular}{|c|c|c|c|c|c|c|}
\hline & $\begin{array}{l}\text { to other } \\
\text { countries }\end{array}$ & & & & & \\
\hline $\mathrm{f}$ & $\begin{array}{l}\text { Availability } \\
\text { of } \\
\text { scholarships } \\
\text { at Canadian } \\
\text { institutions }\end{array}$ & 6 & 19 & 23 & 6 & .001 \\
\hline $\mathrm{g}$ & $\begin{array}{l}\text { A relative, } \\
\text { friend, or } \\
\text { teacher lived } \\
\text { or studied, or } \\
\text { is living or } \\
\text { studying, in } \\
\text { Canada }\end{array}$ & 4 & 20 & 16 & 15 & .017 \\
\hline $\mathrm{h}$ & $\begin{array}{l}\text { My program } \\
\text { of study was } \\
\text { offered in } \\
\text { English in } \\
\text { Canada }\end{array}$ & 5 & 13 & 16 & 21 & .020 \\
\hline $\mathrm{i}$ & $\begin{array}{l}\text { Canadian } \\
\text { institutions } \\
\text { gave me the } \\
\text { most } \\
\text { attractive } \\
\text { conditions } \\
\text { for admission } \\
\text { to my } \\
\text { intended } \\
\text { program }\end{array}$ & 6 & 12 & 27 & 10 & .000 \\
\hline $\mathrm{j}$ & $\begin{array}{l}\text { Ease of } \\
\text { getting a } \\
\text { Canadian } \\
\text { study permit }\end{array}$ & 6 & 18 & 25 & 6 & .000 \\
\hline $\mathrm{k}$ & $\begin{array}{l}\text { Off-campus } \\
\text { work } \\
\text { opportunities } \\
\text { in Canada }\end{array}$ & 7 & 18 & 24 & 6 & .001 \\
\hline 1 & $\begin{array}{l}\text { Post- } \\
\text { graduation } \\
\text { work } \\
\text { opportunities } \\
\text { in Canada }\end{array}$ & 5 & 7 & 21 & 22 & .001 \\
\hline $\mathrm{m}$ & $\begin{array}{l}\text { Post- } \\
\text { graduation } \\
\text { work }\end{array}$ & 7 & 8 & 21 & 19 & .009 \\
\hline
\end{tabular}




\begin{tabular}{|c|c|c|c|c|c|c|}
\hline & $\begin{array}{l}\text { opportunities } \\
\text { in China }\end{array}$ & & & & & \\
\hline $\mathrm{n}$ & $\begin{array}{l}\text { Opportunities } \\
\text { for } \\
\text { permanent } \\
\text { residence in } \\
\text { Canada }\end{array}$ & 3 & 5 & 23 & 24 & .000 \\
\hline o & $\begin{array}{l}\text { The } \\
\text { Canadian } \\
\text { degree I } \\
\text { would obtain } \\
\text { is important } \\
\text { to my family }\end{array}$ & 5 & 14 & 25 & 11 & .002 \\
\hline \multicolumn{7}{|c|}{$\begin{array}{l}\text { I - No idea } \\
\text { II - Not important } \\
\text { III - Somewhat important } \\
\text { IV - Very important } \\
\text { V - Significance }\end{array}$} \\
\hline
\end{tabular}

Seventy eight percent of participants indicated that job opportunity is "somewhat or very important", while $85 \%$ of participants cared about Canada as a safe country. Canada's reputation in general, the quality of education in Canada, and opportunities for permanent residence in Canada also ranked highly. These results (i.e., the most highly rated reasons) are highlighted in Table 2.

Table 2. Highly ranked results from Table 1, sorted by frequency of response

\begin{tabular}{|l|l|c|c|}
\hline \multicolumn{1}{|c|}{ Reasons } & $\begin{array}{c}\text { Participants } \\
\text { who answered } \\
\text { somewhat or } \\
\text { very important }\end{array}$ & Percent \\
\hline a & $\begin{array}{l}\text { Canada's } \\
\text { reputation in } \\
\text { general }\end{array}$ & 52 & 95 \\
\hline c & $\begin{array}{l}\text { The quality of } \\
\text { education in } \\
\text { Canada }\end{array}$ & 51 & 93 \\
\hline b & $\begin{array}{l}\text { Canada's } \\
\text { reputation as a safe } \\
\text { country }\end{array}$ & 47 & 85 \\
\hline
\end{tabular}

\begin{tabular}{|c|l|c|c|}
\hline $\mathrm{d}$ & $\begin{array}{l}\text { The prestige of a } \\
\text { Canadian degree or } \\
\text { diploma }\end{array}$ & 47 & 85 \\
\hline $\mathrm{e}$ & $\begin{array}{l}\text { Opportunities for } \\
\text { permanent } \\
\text { residence in } \\
\text { Canada }\end{array}$ & 47 & 85 \\
\hline $\mathrm{f}$ & $\begin{array}{l}\text { Post-graduation } \\
\text { work opportunities } \\
\text { in Canada }\end{array}$ & 43 & 78 \\
\hline $\mathrm{g}$ & $\begin{array}{l}\text { Post-graduation } \\
\text { work opportunities } \\
\text { in China }\end{array}$ & 40 & 73 \\
\hline
\end{tabular}

To differentiate reasons for studying in Canada from reasons for studying at the participants' specific university, a separate set of questions were asked about why participants chose their current university. The results from these questions are shown in Table 3. The quality of the education and the prestige associated with a degree from that university were the most important reasons, though the cost of the university and the speed with which applications were processed were also important.

Table 3. Answers from participants to the question "How important were the following reasons for choosing this university than another Canadian institution?"

\begin{tabular}{|c|l|c|c|c|c|c|}
\hline \multicolumn{1}{|c|}{ Topics } & I & II & III & IV & V \\
\hline a & $\begin{array}{l}\text { The quality of } \\
\text { education }\end{array}$ & 4 & 2 & 23 & 26 & .000 \\
\hline b & $\begin{array}{l}\text { The prestige of } \\
\text { a } \\
\text { degree/diploma }\end{array}$ & 6 & 1 & 28 & 20 & 000 \\
\hline c & $\begin{array}{l}\text { The cost of } \\
\text { studying }\end{array}$ & 2 & 11 & 29 & 13 & 000 \\
\hline d & $\begin{array}{l}\text { The amount of } \\
\text { financial } \\
\text { support offered }\end{array}$ & 7 & 18 & 23 & 7 & .003 \\
\hline e & $\begin{array}{l}\text { I knew } \\
\text { someone who } \\
\text { studied or is } \\
\text { studying here }\end{array}$ & 7 & 27 & 16 & 5 & 000 \\
\hline
\end{tabular}




\begin{tabular}{|l|l|l|l|l|l|l|}
\hline $\mathrm{f}$ & $\begin{array}{l}\text { They were the } \\
\text { most effective } \\
\text { in providing } \\
\text { information }\end{array}$ & 6 & 12 & 31 & 6 & 000 \\
\hline $\mathrm{g}$ & $\begin{array}{l}\text { The size of this } \\
\text { university }\end{array}$ & 6 & 22 & 24 & 3 & 000 \\
\hline $\mathrm{h}$ & $\begin{array}{l}\text { The } \\
\text { availability of } \\
\text { a particular } \\
\text { program }\end{array}$ & 6 & 10 & 25 & 14 & .002 \\
\hline $\mathrm{i}$ & $\begin{array}{l}\text { Factors } \\
\text { associated with } \\
\text { the location of } \\
\text { this university } \\
\text { (Climate, city } \\
\text { size, proximity } \\
\text { to my country, } \\
\text { etc.) }\end{array}$ & 5 & 12 & 22 & 16 & .011 \\
\hline $\mathrm{j}$ & $\begin{array}{l}\text { This university } \\
\text { had the fastest } \\
\text { admissions } \\
\text { process }\end{array}$ & 6 & 8 & 29 & 12 & .000 \\
\hline $\mathrm{k}$ & $\begin{array}{l}\text { A recruiting } \\
\text { agent } \\
\text { recommended } \\
\text { it }\end{array}$ & 6 & 16 & 23 & 10 & .007 \\
\hline 1 & $\begin{array}{l}\text { Other } \\
\text { important } \\
\text { factors } \\
\text { (specify) }\end{array}$ & 54 & 1 & 0 & 0 & .000 \\
\hline $\begin{array}{l}\text { I - No idea } \\
\text { II - Not important } \\
\text { III - Somewhat important } \\
\text { IV - Very important } \\
\text { V - Significance } \\
\text { Notl responses was } 55 \text { participants }\end{array}$ & & & & \\
\hline
\end{tabular}

The four highest, ranked by importance, responses from Table 3 are shown in Table 4, sorted by frequency of response. Participants in this study indicated that the quality of education was the most important factor in choosing a particular university. Note that, since the participants were still in the midst of their degree, the response about quality of education may refer to both what they have experienced thus far and to the expected continuation of this level of quality.

Table 4. Results from Table 3 sorted by frequency of response

\begin{tabular}{|c|l|c|c|}
\hline \multicolumn{1}{|c|}{ Topics } & $\begin{array}{c}\text { Participants who } \\
\text { answered } \\
\text { somewhat or very } \\
\text { important }\end{array}$ & Percent \\
\hline a & $\begin{array}{l}\text { The quality of } \\
\text { education }\end{array}$ & 49 & 89 \\
\hline b & $\begin{array}{l}\text { The prestige of a } \\
\text { degree/diploma }\end{array}$ & 48 & 87 \\
\hline c & $\begin{array}{l}\text { The cost of } \\
\text { studying }\end{array}$ & 42 & 76 \\
\hline $\mathrm{d}$ & $\begin{array}{l}\text { They had the } \\
\text { fastest } \\
\text { admissions } \\
\text { process }\end{array}$ & 41 & 74 \\
\hline
\end{tabular}

\section{Discussion}

As can be seen from the results, the participants primarily chose to study in Canada because of its reputation and the perceived quality of its education. Likewise, the participants chose their specific university because of the perceived quality of its education. This result is consistent with the research from Yang [23] and Zheng [21], whose participants stated they chose to study in a country outside of China due to its quality of education and its reputation.

There was also a high response (76\%) of participants who chose to study at their current university due to the cost involved, though this reason was only third in importance. The response from participants regarding the cost of living and studying in Canada was still high (72\%) but lower than several other reasons. Although this is consistent with the research from Zheng [21], who suggested that the lower cost of studying was important for Chinese students, it does not seem to be as important to the participants of this study as reputation and educational quality. This is significant, since it suggests that the participants were willing to pay more for a higher quality or more reputable education.

Responses regarding financial support and scholarships indicated that participants saw these also as of lesser importance than other factors. This again 
suggests that the cost was not highly important in the minds of participants.

The finding that Canada's reputation as a safe country ranked higher than both the costs involved and desire to live in Canada is a result not mentioned in the cited literature. Since this finding appears not to have been explored in detail by researchers in this field, it is important for future researchers to examine this finding further. It is possible that Canada's global reputation is at least partially built on the idea that it is a safe country. However, since the quality of its education was ranked higher than safety, it is possible that researchers typically only consider Canada's reputation in terms of its educational quality rather than other aspects such as safety.

Noticeably low on the list of reasons was family influence, as queried in Table 1 (o), and the desire to study in a country where there were friends and/or family, as queried in Table 2 (e). The participants appeared to rank the importance of being encouraged by their families (resident either in the home or the receiving country) to study abroad as less important than the factors noted above, or they were unwilling to disclose this information to the researchers. Bearing this in mind, it is possible that family influence was interpreted by participants in this case as the more general Chinese attitude towards the importance of education. In other words, participants may have identified family-related factors as referring to the traditional influence that families have held over its younger members in relation to the importance of achieving a high-quality education, and the degree to which participants believed they could meet such family expectations in Canada.

It is also important to note that participants ranked highly the possibility of living $(85 \%)$ and working (78\%) in Canada. Aside from this being consistent with the research from Hung, Shive, Wang, and Diu [18] and Yang [23], it also indicates that the participants were quite willing to discuss living and working outside of China. Although it is possible that some participants were hesitant to mention it, and hence gave a lower rating to this item in their questionnaire responses, many of the participants did rate it as somewhat important or very important. The higher ranking of this particular item may suggest that many Chinese students are becoming more willing to discuss more openly now than in the past the possibility they may actually be looking for opportunities to live and work outside of China. This factor may be becoming more of an explicit than hidden reason.

\section{Conclusion}

This paper reported on a study investigating explicit or stated reasons for Chinese students studying in Canada. Such a study was warranted to test what direct reasons Chinese students may give so that potential unstated reasons could be explored in later studies, as it is quite possible that Chinese students do not readily disclose certain reasons for studying internationally.

In this study of 55 Chinese international students, most of them stated that the most important factors influencing their choice to study in Canada were its reputation $(95 \%)$ and the quality of education it provided (93\%). Further, most of them chose their particular university for its quality of education (89\%) and the prestige of its degrees (87\%). However, secondary reasons just below these included the belief that Canada was a safe country in which to live $(85 \%)$ and that they had a good possibility of living $(85 \%)$ and working $(78 \%)$ in Canada after graduation.

These results are consistent with the literature on reasons for Chinese students studying internationally and in Canada, except for the high importance placed on safety. Future research will involve interviews with some of these same participants to explore more deeply some of the factors that are not so readily shared when the medium is a questionnaire, and the researcher has not necessarily established trust or rapport with the study participants. This subsequent study may be better positioned to uncover important information regarding reasons for studying in Canada that is perhaps equally relevant but less readily attainable.

Based on the current results, Canadian Universities would do well to promote their reputation for offering high-quality education to students and Canada's reputation as safer than other countries. Another possible avenue to consider would be advertising opportunities for career and immigration counselling, since those are also highly ranked reasons for studying in Canada but which are not usually part of a University's recruitment portfolio.

\section{References}

[1] Alonso, J.A, International Migration and Development: A Review in Light of the Crisis (CDP Background Paper No. 11 (E)). United Nations Development Policy and Analysis Division, New York, NY, 2011.

[2] A.M. Doorbar, The English language market: a global perspective. Paper presented at annual NAFSA: Association of International Educators Conference, 2001. 
[3] A. Tanner, Brain drain and beyond: returns and remittances of highly skilled migrants. Global Migration Perspectives No. 24 (Geneva, Global Commission on International Migration). 2005.

[4] Carlson, J.S., B.B. Burn, J. Useem, and D. Yachimowicz, Study abroad: the experience of American undergraduates. Westport, CT: Greenwood Press, 1990.

[5] C.C. Lai-wan, B., Eric, and C. C. Hoi-yan, Attitudes to and practices regarding sex selection in China. Prenatal Diagnosis, 26, 610-613, 2006.

[6] Central Intelligence Agency. The world factbook: China. Retrieved January 14, 2006, from http://www.cia.gov/cia/publications/factbook/geos/ch.html, 2005.

[7] Chang, B.-J., and C. Kemp, China. In C. Kemp \& L. A. Rasbridge (Eds.), Refugee and immigrant health: A handbook for health professionals (pp. 132-141). Cambridge: Cambridge University Press, 2004.

[8] Chin, P. Chinese. In J. G. Lipson \& S. L. Dibble (Eds.), Culture and clinical care. San Francisco: UCSF Nursing Press, 2005.

[9] C.M. Sanchez, M. Fornerino, and M. Zhang, M. Motivations and the Intent to Study Abroad Among U.S., French, and Chinese Students. Journal of Teaching in International Business, 18(1), 27-52, 2006.

[10] D. Ashley, and Y. Jiang. Mao's Children in the New China. Beijing: Routledge, 2000.

[11] Deardorff, D. K., H. de Wit, and J.D. Heyl. (Eds.), The SAGE handbook of international higher education. Sage, 2012.

[12] Ditto, S, Red tape iron never the iranian guest for U.S. Education. Washington. USA, 2014.

[13] F. Maiworm, and U. Teichler, The first years of the ECTS in the view of the students. (ERASMUS Monographs No.20. Wekstattberichte-Band 47). Brussels: Commission of the European Communities, 1995.

[14] G. Baldacchino, The brain rotation and brain diffusion strategies of small islanders: considering 'movement' in lieu of 'place'. Globalisation, Societies and Education, 4(1), 143154. 2000, 2006.

[15] Guruz, K. Higher Education and International Student Mobility in the Global Knowledge Economy: Revised and Updated Second Edition. SUNY Press, 2011.

[16] H. Barnick, Personal motivations, political pathways: Canadian university students studying in Australia. (Master dissertation, Concordia University, 2006). Retrieved from ProQuest Digital Dissertations. (AAT MR28867), 2006.
[17] H. Do, EthnoMed: Chinese cultural profile. Retrieved February 29, 2008, from http://www.ethnomed.org/ ethnomed/cultures/chinese/chinese_cp.html, 2000.

[18] Hung, F., G. Shive, X. Wang, and J. Diu, A report on the export potential of Hong Kong's education services. A Consultancy Study for the Hong Kong Trade and Development Council. Hong Kong, 2005, 2000.

[19] J. F. Hamrick, The college choice experiences of Pakistani undergraduates in the United States. (Doctoral dissertation, Panjab University, 1998). Retrieved from ProQuest Digital Dissertations. (AAT 3287530), 2007.

[20] Ji, R, An Analysis of Mainland Chinese Students' Decision to Choose Canada as Their Study Destination (Doctoral dissertation, Concordia University), 2011.

[21] J. Zheng, Exploring international student mobility: Neoliberal globalization, higher education policies and Chinese graduate student perspectives on pursuing higher education in Canada. (Doctor dissertation, University of Alberta, 2010). Retrieved from ProQuest Digital Dissertations. (AAT MR60582), 2010.

[22] K. Hardee, Z. Xie, and B. Gu. Family planning and women's lives in rural China. International Family Planning Perspectives, 30(2), 68-76, 2003.

[23] M. Yang, What attracts Mainland Chinese students to Australian higher education. Studies in Learning, Evaluation, Innovation and Development, 4(2), 1-12, 2007.

[24] New Release (2015). Canada welcomed record numbers from China in 2014, 2015. Retrieved from http://news.gc.ca/web/article-en.do?nid=981929

[25] N. Kemp, Higher Education and International Student Mobility in the Global Knowledge Economy. By K. Guruz: New York: SUNY Press. British Journal of Educational Studies, 59(3), 355-357, 2011.

[26] N. Pimpa, A family affair: the effect of family on Thai students' choices of international education. Higher Education, 49(4), 431-448, 2005.

[27] P. Brown, H. Lauder, and D. Ashton, Education, Globalisation and the Future of the Knowledge Economy, European Educational Research Journal, 7,2,131-56, 2008.

[28] Peilin, L. Chinese Society-Change and Transformation (Vol. 25). Routledge, 2012.

[29] Rizvi, F. International education. In N.C. Burbules \& C.A. Torres. (Eds), Globalization and education. (pp.205226). New York: Routledge, 2000.

[30] Sahoo, S., and B.K. Pattanaik. Global Diasporas and Development: Socioeconomic, Cultural, and Policy Perspectives. Springer Science \& Business Media, 2013. 
[31] Simon, D. F., and C. Cao. China's emerging technological edge: assessing the role of high-end talent. Cambridge University Press, 2009.

[32] T. Mazzarol, and G. N. Soutar, Push-pull factors influencing student destination choice. International Journal of Education Management, 16(2), 82-90, 2002.

[33] X. Liu, X, Han. In C.R. Ember \& M. Ember (Eds.), Encyclopedia of medical anthropology: Health and illness in the world's cultures (pp. 703-717). New York: Kluwer Academic/Plenum Publishers, 2004.

[34] Wood, R. (2014). Study in Canada special: The experts answer your question. Retrieved from http://www.studentworldonline.com/article/study-incanada-special-the-experts-answer-your-questions/194/

[35] W. Shen, Memorandum. 2006. Retrieved from http://www.publications.parliament.uk/pa/cm200506/cmsel ect/cmhaff/775/775awe31.htm

[36] Xinhua News Agency, Why Overseas Chinese Students Not Returning to China? 2012. Retrieve from http://www.chinasmack.com/2013/stories/why-areoverseas-chinese-students-not-returning-to-china.html

[37] Y. Hai, A study of the motivations of Chinese students in the United States: Impacts of internationalization on Chinese higher education. (Master dissertation, Stanford University, 2007), 2007. Retrieved from Stanford University website:

http://suse-ice.stanford.edu/monographs/HaiYang.pdf

[38] Y. Wu, and S. Mao, Deceptive myth by study abroad agency. Study Oversea, 2004(20), 50-51, 2004.

[39] Z. Wang, Key factors that influence recruiting young Chinese students. International Education Journal. 8(2), 3748, 2007. 